\title{
In vitro Evaluation of Calcium Phosphate Precipitation on Possibly Bioactive Titanium Surfaces in the Presence of Laminin
}

\author{
Kostas Bougas $^{1,4}$, Victoria Franke Stenport ${ }^{2,4}$, Fredrik Currie ${ }^{3}$, Ann Wennerberg ${ }^{1,4}$ \\ ${ }^{1}$ Department of Prosthodontics, Faculty of Odontology, Malmö University, Malmö, Sweden. \\ ${ }^{2}$ Department of Prosthodontics, Faculty of Odontology, Sahlgrenska Academy, University of Gothenburg, Gothenburg, \\ Sweden. \\ ${ }^{3}$ Promimic AB, Gothenburg, Sweden. \\ ${ }^{4}$ Department of Biomaterials, Institute of Clinical Sciences, Sahlgrenska Academy, University of Gothenburg, Gothenburg, \\ Sweden.
}

\author{
Corresponding Author: \\ Kostas Bougas \\ Department of Prosthodontics, Faculty of Odontology, Malmö University \\ 20506 Malmö \\ Sweden \\ Phone: +46406658520 \\ Fax: +46 406658503 \\ E-mail: kostas.bougas@mah.se
}

\begin{abstract}
Objectives: The aim of the present study was to evaluate calcium phosphate precipitation and the amount of precipitated protein on three potentially bioactive surfaces when adding laminin in simulated body fluid.

Material and Methods: Blasted titanium discs were prepared by three different techniques claimed to provide bioactivity: alkali and heat treatment $(\mathrm{AH})$, anodic oxidation ( $\mathrm{AO}$ ) or hydroxyapatite coating (HA). A blasted surface incubated in laminincontaining simulated body fuid served as a positive control (B) while a blasted surface incubated in non laminin-containing simulated body fuid served as a negative control (B-). The immersion time was 1 hour, 24 hours, 72 hours and 1 week. Surface topography was investigated by interferometry and morphology by Scanning Electron Microscopy (SEM). Analysis of the precipitated calcium and phosphorous was performed by Energy Dispersive X-ray Spectroscopy (EDX) and the adsorbed laminin was quantified by iodine $\left({ }^{125} \mathrm{I}\right)$ labeling.

Results: SEM demonstrated that all specimens except for the negative control were totally covered with calcium phosphate $(\mathrm{CaP})$ after 1 week. EDX revealed that B- demonstrated lower sum of Ca and P levels compared to the other groups after 1 week. Iodine labeling demonstrated that laminin precipitated in a similar manner on the possibly bioactive surfaces as on the positive control surface.

Conclusions: Our results indicate that laminin precipitates equally on all tested titanium surfaces and may function as a nucleation center thus locally elevating the calcium concentration. Nevertheless further studies are required to clarify the role of laminin in the interaction of biomaterials with the host bone tissue.
\end{abstract}

Keywords: laminin; titanium; body fluid; calcium phosphates; biomaterials.

Accepted for publication: 19 July 2011

To cite this article:

Bougas K, Stenport VF, Currie F, Wennerberg A. In vitro Evaluation of Calcium Phosphate Precipitation on Possibly Bioactive Titanium Surfaces in the Presence of Laminin.

J Oral Maxillofac Res 2011 (Jul-Sep);2(3):e3

URL: http://www.ejomr.org/JOMR/archives/2011/3/e3/v2n3e3ht.pdf

doi: $10.5037 /$ jomr.2011.2303 


\section{INTRODUCTION}

Bone anchored titanium implants are used in the rehabilitation of edentulism. The bone formation around titanium implants has been extensively investigated, however despite this the biological phenomenon is yet to be understood to the full extend. It has been suggested that a biochemical bonding between bone tissue and titanium surfaces can be obtained by using bioactive implants. Bioactivity has been defined as "the characteristics of an implant material which allows it to form a bond with living tissues" [1]. However, bioactivity is today defined in more general terms implying a chemical influence on bone tissue [2] Theoretically, the advantages with bioactive implants could be rapid biochemical stimulation, and that the interaction between implant and bone may enhance early bone formation.

Chemical modification methods of titanium implant surfaces have been proposed to enhance bone growth. Some of these techniques are fluoride etching [3] , alkali-heat treatment [4]], anodic oxidation $[\underline{5}, \underline{6}]$, coatings of calcium phosphates in sol-gels [7], and immobilization of organic bio-molecules or polymers on the surface $[\underline{8}, 9]$. These techniques alter not only the surface chemistry but also the topography, which both may contribute to an increased attachment to the bone. However, the exact mechanism of bone formation on the different surfaces has not been fully clarified.

A variety of materials and surface modifications have been evaluated in vitro by using the simulated body fluid (SBF) model [10-12]. SBF is defined as an acellular, protein-free solution with ion concentrations approximately equal to those of human blood plasma [13-15]. The nucleating capacity of a biomaterial can be observed by immersing it in SBF [16]. It has been suggested that the nucleation of calcium/phosphates mimics the initial mineralization of bone on the implant surface. In a review on the usefulness of SBF in predicting the in vivo bone bioactivity, a correlation has been described between apatite formation in SBF models and bone bioactivity in vivo [17].

However, compared to the SBF model, the in vivo process is much more complex and numerous proteins, enzymes and biological factors play an important role in this process [18]. Some studies applied bovine serum albumine (BSA) in various concentrations in SBF-solutions. The results indicated that the BSA alters the nucleation rate, morphology, composition and crystallinity of the $\mathrm{Ca} / \mathrm{P}$ precipitates $[18-20]$. This is of interest, since it has been discussed if protein adsorption may contribute to cell behaviour, and thus can be regarded as a fundamental reaction [21]. Thereby, it has been speculated that the protein adsorption could play a role in the bioactivity of specific materials.

Laminins are heterotrimeric glycoprotein molecules included in the proteins that are involved in cell adhesion on biomaterials [22] possessing the ability to bind to a protein family known as integrins, especially $\beta 1$ and $\beta 2$ integrins [23] ]. Integrins are integral membrane glycoproteins which mediate cell-to-cell and cell-to-matrix interactions. Integrins have not only the ability to mediate cell adhesion to extracellular matrix, but they also facilitate the cell communication [24]. By their cytoplasmic domains, they participate in the assembly of the cytoskeleton and thereby influencing cell migration, adhesion of epithelial cells and hemidesmosome formation [23]. In vitro studies suggest that laminin-1 recruits osteoprogenitors cells through an attachment effect $[\underline{25}, 26]$, and to human osteoblast-like cells through the $\beta 1$ integrin subunit [27].

The aim with the present study was to evaluate the nucleating behaviour of three different surfaces, claimed to be bioactive and to compare them with a blasted control surface in the presence of laminin in a simulated body fuid model since laminin seems to act as a promising osteoprogenitor recruiting protein.

\section{MATERIAL AND METHODS}

\section{Surface preparations}

In total, 75 discs $($ diameter $=8 \mathrm{~mm}$, thickness $=1 \mathrm{~mm})$ of titanium grade 4 were used in the study. The samples were blasted with $\mathrm{Al}_{2} \mathrm{O}_{3}$ powder with an average particle size of $120 \mu \mathrm{m}$ with a force of $3.5 \mathrm{~kg}$ and from a distance of $15 \mathrm{~mm}$, and were subsequently cleaned ultrasonically in diluted Extran MA01 and absolute ethanol, and were dried at $60{ }^{\circ} \mathrm{C}$ for $24 \mathrm{~h}$. The specimens were then divided into five equally sized groups $(n=15)$. A group of blasted discs incubated in laminin-containing SBF served as a positive control (B), while a group of blasted specimens incubated in non laminin-containing SBF served as a negative control (B-). The other three groups were treated as following.

\section{Alkali and heat treatment (AH)}

Alkali and heat treatment was performed as described in the literature $[\underline{15}, \underline{28}, \underline{29}]$. In brief, the discs were soaked in $5 \mathrm{M}$ aqueous $\mathrm{NaOH}$ for $24 \mathrm{~h}$ at $60^{\circ} \mathrm{C}$, rinsed with distilled water and dried at $40^{\circ} \mathrm{C}$ for $24 \mathrm{~h}$. Subsequently, the discs were heated until reaching $600^{\circ} \mathrm{C}$ by increasing the temperature by $5{ }^{\circ} \mathrm{C} / \mathrm{min}$ in an electrical furnace (Bitatherm, Bita Laboratory Furnaces, Israel) and were kept at $600{ }^{\circ} \mathrm{C}$ for $2 \mathrm{~h}$. The discs were left in the furnace until they cooled down to room temperature. 


\section{Anodic oxidation (AO)}

The samples were prepared in a mixed electrolyte containing calcium ions by using the Micro Arc Oxidation (MAO) method in galvanostatic mode as described by Sul et al. [30]. More specifically, the electrochemical cell was composed of platinum plates as cathodes, and a titanium anode at the centre. A computer interfaced with a DC power supply was used to record currents and voltages at milliseconds intervals. The content of ripple was controlled to less than $0.1 \%$ [ $\underline{31}$ ]. Surface analysis of the oxidized group demonstrated the following properties: a calcium content of 11 atomic percent in the newly formed oxide with a $1.2 \mu \mathrm{m}$ thickness, $24 \%$ porosity of porous structure and anatase and rutile crystal structure $[\underline{32}, \underline{33}]$.

\section{Hydroxyapatite coating ( $\mathrm{HA})$}

A thin hydroxyapatite layer $(<50 \mathrm{~nm})$ was obtained by dipping the titanium discs into a solution containing surfactants, water, organic solvent and crystalline nanoparticles of hydroxyapatite with a $\mathrm{Ca} / \mathrm{P}$ ratio of 1.67. The diameter of the hydroxyapatite particles was approximately $10 \mathrm{~nm}$. After the dipping procedure the discs were let to dry in open air for $30 \mathrm{~min}$, allowing the organic solvent to evaporate. To remove all dispersing agents, the discs were subjected to heat treatment at $550{ }^{\circ} \mathrm{C}$ for $5 \min [\underline{34}]$.

\section{Radio Labelling of Laminin}

Laminin (Sigma-Aldrich, Stockholm, Sweden) was labelled with iodine-125 ( ${ }^{125}$ I) (Amersham Pharmacia Biotech, Uppsala, Sweden) using the Iodo-Bead iodination method (Pierce, USA). The beads were rinsed in phosphate buffered saline (PBS) at $\mathrm{pH} 6.5$ with $0.25 \mathrm{mM}$ sodium azide. The sodium iodide- 125 was mixed in PBS, and equilibrated for $5 \mathrm{~min}$. Subsequently, laminin in PBS was added, and incubated for 7 min under gentle stirring. The solution with the labeled protein was dialyzed with $50 \mathrm{mM}$ KI added against PBS using dialysis tubings (Spectrapor, Rancho Dominguez, CA, USA) with a pore size of $3500 \mathrm{Da}$. Small volumes were taken at different times from the dialysate, and the activity was checked throughout the procedure. The labelled protein solution was dialyzed in several steps until the activity fell below $5000 \mathrm{CPM} /$ $\mathrm{ml}$. The protein concentration was determined by spectrophotometry (Shimadzu UV-1601PC, Columbia, MD, USA) at $280 \mathrm{~nm}$. A series of solutions with known concentrations of respective unlabeled protein was used for the calibration.

\section{SBF immersion}

The revised SBF (r-SBF) used in this study was prepared according to the literature [35]. In brief, $5.403 \mathrm{~g}$ $\mathrm{NaCl}$ (Merck, Darmstadt, Germany), $0.740 \mathrm{~g} \mathrm{NaHCO}_{3}$ (Merck, Darmstadt, Germany), $2.046 \mathrm{~g} \mathrm{Na}_{2} \mathrm{CO}_{3}$ (Merck, Darmstadt, Germany), $0.225 \mathrm{~g} \mathrm{KCl}$ (Merck, Darmstadt, Germany), $0.230 \mathrm{~g} \mathrm{~K}_{2} \mathrm{HPO}_{4} \cdot 3 \mathrm{H} 2 \mathrm{O}$ (Merck, Darmstadt, Germany), $0.311 \mathrm{~g} \mathrm{MgCl} \cdot 6 \mathrm{H}_{2} \mathrm{O}$ (Merck, Darmstadt, Germany), 11.928 g 2-(4-(2-hydroxyethyl)1-piperazinyl) ethanesulfonic acid (HEPES) (Reach Organics Inc., Cleveland, Ohio, USA), $0.293 \mathrm{~g} \mathrm{CaCl}_{2}$ (KEBO Lab AB, Spånga, Sweden) and $0.072 \mathrm{~g} \mathrm{Na}_{2} \mathrm{SO}_{4}$ (Merck, Darmstadt, Germany) were dissolved in $1,000 \mathrm{ml}$ distilled water. HEPES was dissolved in 100 $\mathrm{ml}$ distilled water before being added to the solution and the final $\mathrm{pH}$ was adjusted to 7.4 at $37^{\circ} \mathrm{C}$. Laminin marked with ${ }^{125} \mathrm{I}$ was added to adjust to a final concentration of $300 \mathrm{ng} / \mathrm{ml}$, which corresponds to the concentration of laminin included in the human blood plasma [36].

The discs were immersed in $25 \mathrm{ml} \mathrm{r}-\mathrm{SBF} / \mathrm{laminin}$ in separate sealed polystyrene vials, and incubated at $37^{\circ} \mathrm{C}$. After immersion for $1 \mathrm{~h}, 1$ day, 3 days and 1 week the r-SBF/laminin immersion was interrupted, and the specimens were rinsed with distilled water, in order to remove any loosely attached calcium phosphates. Thereafter, the specimens were left to dry at room temperature, and ultimately sealed in dry vials. Three samples for each type of surface were not immersed in r-SBF/laminin $(0 \mathrm{~h})$.

\section{Laminin quantification}

After immersion in r-SBF/laminin, the specimens were transferred to a gamma counter (Packard Cobra II, Canberra, USA), and the activity was measured for $10 \mathrm{~min}$. To correlate the gamma counter values to the adsorbed amounts, known volumes with known labelled protein concentrations were measured in the gamma counter. The surfaces and proteins did not adsorb free ${ }^{125} \mathrm{I}$ from the solutions, and the proteins were not noticeably affected by the labelling procedure [37].

\section{Topographic characterization}

The specimens were topographically analyzed after immersion in $\mathrm{r}-\mathrm{SBF} / \mathrm{laminin}$ with an interferometer (MicroXam, Phase-Shift, Tucson, Arizona, USA) operating in a wave length of $\lambda=550 \mathrm{~nm}$.

A Gaussian filter with size $50 \times 50 \mu \mathrm{m}^{2}$ was applied to separate roughness from form and waviness. Thereafter, the surface roughness was calculated using the following topographical parameters defined as essential for describing the topography of biomaterial surfaces [38]. $\mathrm{S}_{\mathrm{a}}=$ Arithmetic mean height deviation from a mean plane $(\mu \mathrm{m})$.

$\mathrm{S}_{\mathrm{ds}}=$ Density of summits, i.e. the number of summits of a unit sampling area $\left(\mu \mathrm{m}^{-2}\right)$. 
$\mathrm{S}_{\mathrm{dr}}=$ Developed interfacial area ratio, i.e. the ratio of the increment of the interfacial area of a surface over the sampling area (\%).

Calculations of group means and standard deviations for each surface preparation and time point were performed.

\section{Scanning electron microscopy/energy dispersive $\mathrm{X}$-ray analysis (SEM/EDX)}

For the SEM analysis, a LEO Ultra 55 FEG SEM equipped with an Oxford Inca EDX system, operating at 8 and $10 \mathrm{kV}$ was used. The samples were examined without surface sputtering. Micrographs were recorded at different magnifications to investigate both the surface coverage and the morphology of the crystals. EDX analysis at a magnification of 150 times was performed to describe the atomic composition. Two discs for each preparation and incubation time were analyzed, and mean value was calculated.

\section{Statistical analysis}

The normal distribution of the variables was controlled by Kolmogorov-Smirnov normality test. Statistical analysis was performed with Statistical Package for the Social Sciences for Windows, version 18 (SPSS ${ }^{\circledR}$, Chicago, Illinois, USA) using One-way ANOVA (Analysis of Variance). The statistical significance level was set at 0.05 . Multiple paired comparisons were performed by Bonferroni Post-Hoc test with the statistical significance level defined at 0.05 .



Figure 1. Mean values and standard errors of $\mathrm{S}$ for the four different surface groups. $\mathrm{B}=$ blasted titanium; $\mathrm{AH}=$ alkali and heat treated; $\mathrm{AO}=$ anodically oxidized; $\mathrm{HA}=$ hydroxyapatite coated $\mathrm{B}-=$ blasted titanium incubated in non laminin containing SBF. Mean values and standard errors are presented.

\section{RESULTS}

\section{Topographical characterization}

The AH surface demonstrated small height deviation and large density of irregularities. The surface enlargement is explained by the large $\mathrm{S}_{\mathrm{ds}}$ value. After 1 week of incubation, no differences with respect to surface roughness was possible to detect among the surface groups incubated in laminin-containing SBF. Regarding the negative control B-, $\mathrm{S}_{\mathrm{ds}}$ and $\mathrm{S}_{\mathrm{dr}}$ remained stable throughout the incubation, and were significantly lower when compared to the specimens incubated in presence of laminin.

\section{$S_{a}$ mean values}

The AH surface and the negative control had a lower mean $\mathrm{S}_{\mathrm{a}}$ than the other surfaces prior to immersion. The AH surface and the negative control B- still had the lowest $\mathrm{S}_{\mathrm{a}}$ of all surface groups after $72 \mathrm{~h}$ while no significant differences in mean $S_{a}$ could be detected among the surface groups after 1 week of incubation (Figure 1).

\section{$S_{d s}$ mean values}

The AH surface had at all time points, the highest surface density of all the surface groups except for the AH surface after $72 \mathrm{~h}$ of incubation. Group B had throughout the incubation period the lowest density of summits. After having incubated the samples for 1 week, the negative control B- still demonstrated the lowest $\mathrm{S}_{\mathrm{ds}}$ value (Figure 2).

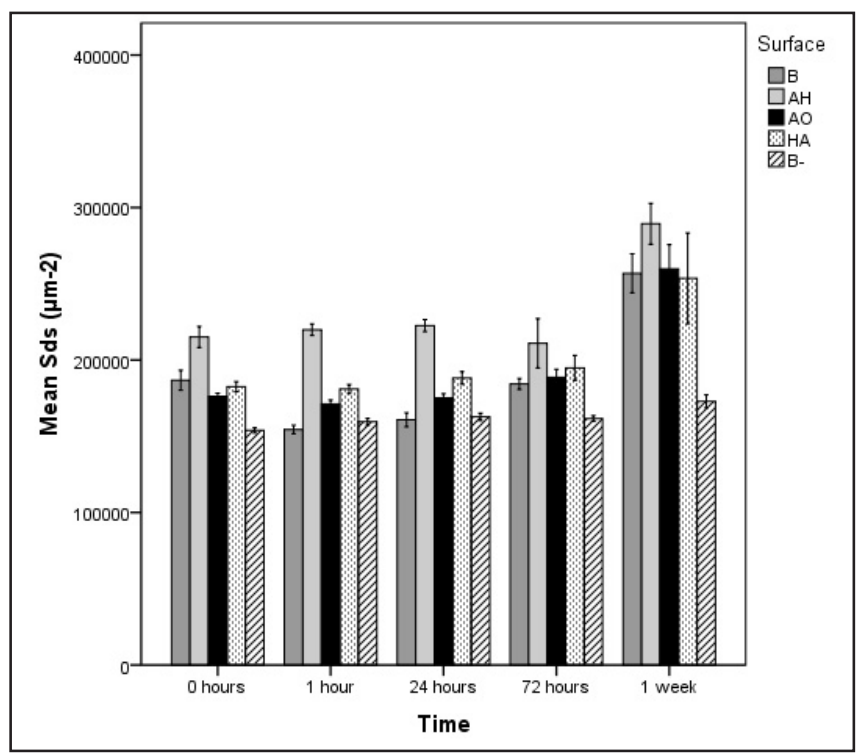

Figure 2. Mean values and standard errors of $S_{d s}$ for the four different surface groups. $\mathrm{B}=$ blasted titanium; $\mathrm{AH}=$ alkali and heat treated; $\mathrm{AO}=$ anodically oxidized; $\mathrm{HA}=$ hydroxyapatite coated; B- = blasted titanium incubated in non laminin containing SBF. Mean values and standard errors are presented. 


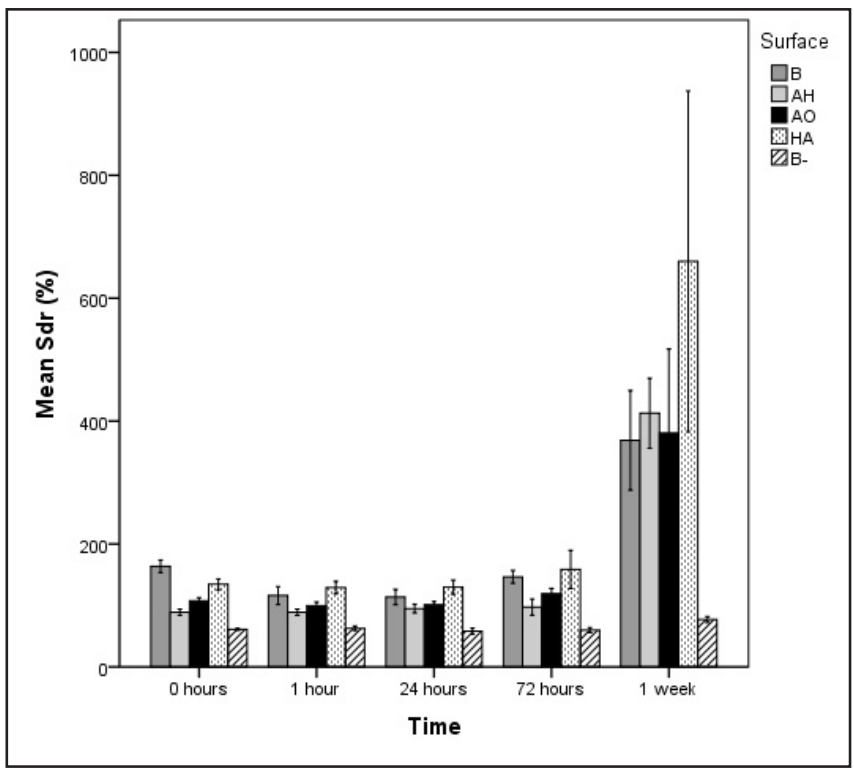

Figure 3. $\mathrm{S}_{\mathrm{dr}}$ of the four different surface groups. $\mathrm{B}=$ blasted titanium; $\mathrm{AH}=$ alkali and heat treated; $\mathrm{AO}=$ anodically oxidized; $\mathrm{HA}=$ hydroxyapatite coated; $\mathrm{B}-$ = blasted titanium incubated in non laminin containing SBF. Mean values and standard errors are presented.

\section{$S_{d r}$ mean values}

The blasted surface (B) had the highest $\mathrm{S}_{\mathrm{dr}}$ mean value of all the other surface groups prior to immersion in SBF and the negative control the lowest (B-). After 1 week, no significant differences could be detected among the groups except for the negative control B- being the only surface with significantly lower $\mathrm{S}_{\mathrm{dr}}$ throughout the incubation period (Figure 3).

\section{SEM/EDX}

SEM images with a $\times 5,000$ magnification acquired prior to incubation in SBF, demonstrated differences in surface morphology when comparing the control
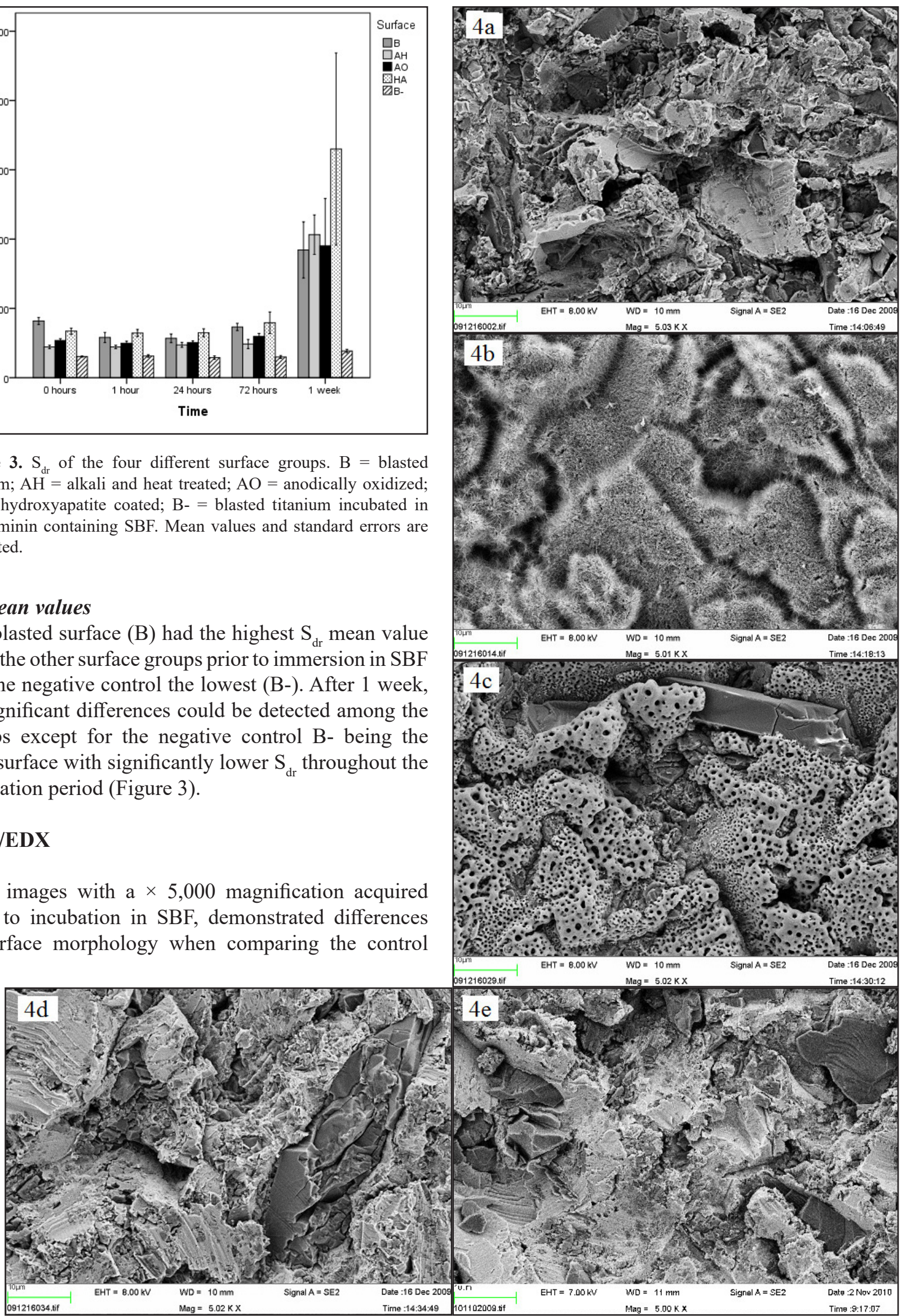

Figure 4. SEM images of Ti-discs prior to incubation in SBF (x 5,000)

(a) B = blasted; (b) $\mathrm{AH}=$ alkali and heat treated; (c) $\mathrm{AO}=$ anodically oxidized; (d) HA = hydroxyapatite coated; (e) B- = blasted titanium incubated in non laminin containing SBF. The bar presents $10 \mu \mathrm{m}$. 
blasted surface (Figures 4 a and 4 e) to the alkali and heat treated, which possessed a smooth surface, covered with microscopic spike-like structures (Figure 4 b) and to anodic oxidated ones which had a porous appearance (Figure $4 \mathrm{c}$ ). However, no differences were observed in surface morphology when comparing the nano-sized hydroxyapatite coated surface (Figure $4 \mathrm{~d}$ ) to the control surface B. Both surfaces had sharp-edged appearances, which probably depended on the blasting procedure, and included some $\mathrm{Al}_{2} \mathrm{O}_{3}$ crystals. Nano-sized hydroxyapatite crystals could not be observed in this magnification. After 1 week, no differences in surface morphology could be observed when comparing the SEM images, since all the samples were totally covered with a homogenous layer of crystals (Figures $5 \mathrm{a}-\mathrm{d}$ ). Nevertheless, the blasted surface incubated solely in SBF appeared to be only partially covered by crystals (Figure 5 e).

\section{EDX}

\section{Calcium phosphate (CaP)}

The total amount of calcium phosphate $(\mathrm{CaP})$ crystals on the surface of the titanium discs was measured with EDX by measuring and adding the relative elemental amount of calcium $(\mathrm{Ca})$ and phosphorous $(\mathrm{P})$ present on the surface. The mean sum of $\mathrm{Ca}$ and $\mathrm{P}$ was statistically significant higher $(p<0.05)$ for the AH surface throughout the incubation time with a greater difference at $24 \mathrm{~h}$ and $72 \mathrm{~h}$, and the differences were statistically significant $(\mathrm{p}<0.05)$. After 1 week no significant differences could be detected among the groups incubated in laminin containing SBF. The negative control B- failed to follow the same CaP precipitation pattern as the surfaces incubated in laminin containing SBF and after $24 \mathrm{~h}$ it demonstrated lower levels of total $\mathrm{CaP}$, despite showing an ascending trend (Figure 6).
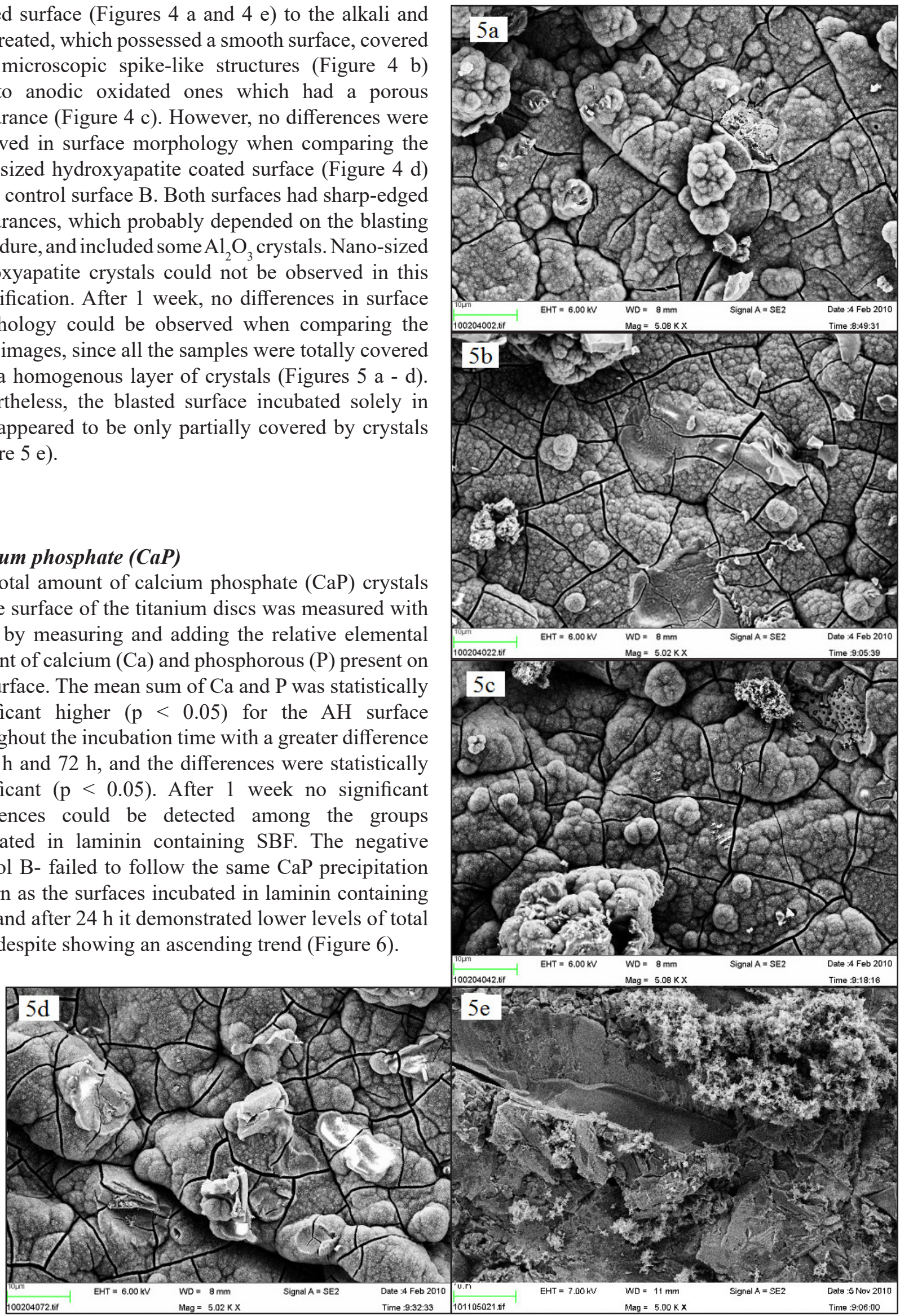

Figure 5. SEM image of a Ti-discs after incubation in SBF for 1 week (x 5,000) (a) B = blasted; (b) $\mathrm{AH}=$ alkali and heat treated; (c) $\mathrm{AO}$ = anodically oxidized; (d) HA = hydroxyapatite coated; (e) B- = blasted titanium incubated in non laminin containing SBF. The size of the bar is $10 \mu \mathrm{m}$. 


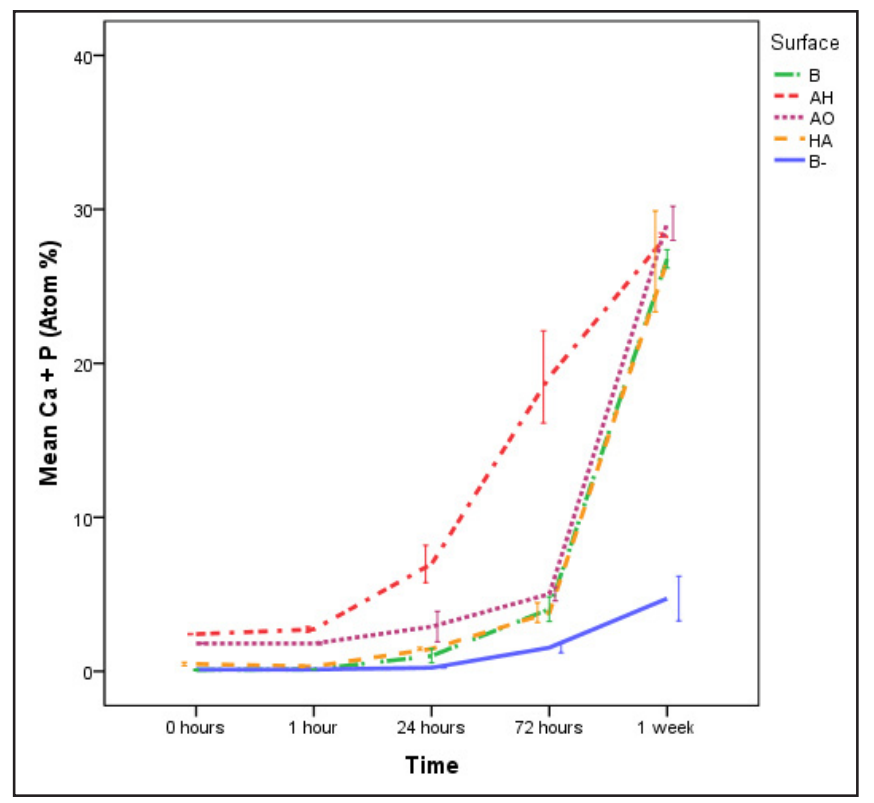

Figure 6. Total amount of precipitated calcium and phosphorous calculated from EDX measurements. $\mathrm{B}=$ blasted titanium; $\mathrm{AH}=$ alkali and heat treated; $\mathrm{AO}=$ anodically oxidized; $\mathrm{HA}=$ hydroxyapatite coated; B- = blasted titanium incubated in non laminin containing $\mathrm{SBF}$. Mean values and standard errors are presented.

\section{Calcium/Phosphorous ratio (Ca/P Ratio)}

The proposed bioactive surfaces, i.e. AH, AO and HA treated samples, demonstrated a higher $\mathrm{Ca} / \mathrm{P}$ ratio than both the blasted control samples prior to incubation in SBF. Furthermore, calcium and phosphorous signals were recorded at an earlier stage on the bioactive surfaces compared to the blasted group. At the non-incubated samples, no phosphorous (P) was detected on the $\mathrm{AH}$ surface, which in Figure 7 is reported as missing value. The high initial $\mathrm{Ca}$ content on the surface, contributed to a high $\mathrm{Ca} / \mathrm{P}$ ratio where after $1 \mathrm{~h}$ of incubation we could also detect P. After $1 \mathrm{~h}$, all the possibly bioactive surfaces had still higher $\mathrm{Ca} / \mathrm{P}$ ratio than the blasted groups with the $\mathrm{AH}$ treated group showing the highest ratio, and after $24 \mathrm{~h}$ the blasted group incubated in laminin containing SBF had a significantly higher $\mathrm{Ca} / \mathrm{P}$ ratio than the negative control B-. After $72 \mathrm{~h}$, all the groups had a $\mathrm{Ca} / \mathrm{P}$ ratio around 1.67 , corresponding to hydroxyapatite crystalline formation. When the $\mathrm{Ca} / \mathrm{P}$ ratio was examined after 1 week of incubation, no statistically significant differences were detected among the different surface groups (Figure 7).

\section{Amount precipitated laminin}

The mean values for the amount precipitated laminin from the SBF on different surfaces and time points are presented in Table 1. The groups $\mathrm{B}, \mathrm{AH}$ and $\mathrm{AO}$ reached their maximum laminin precipitation levels already after $1 \mathrm{~h}$ while the HA group reached its top level after

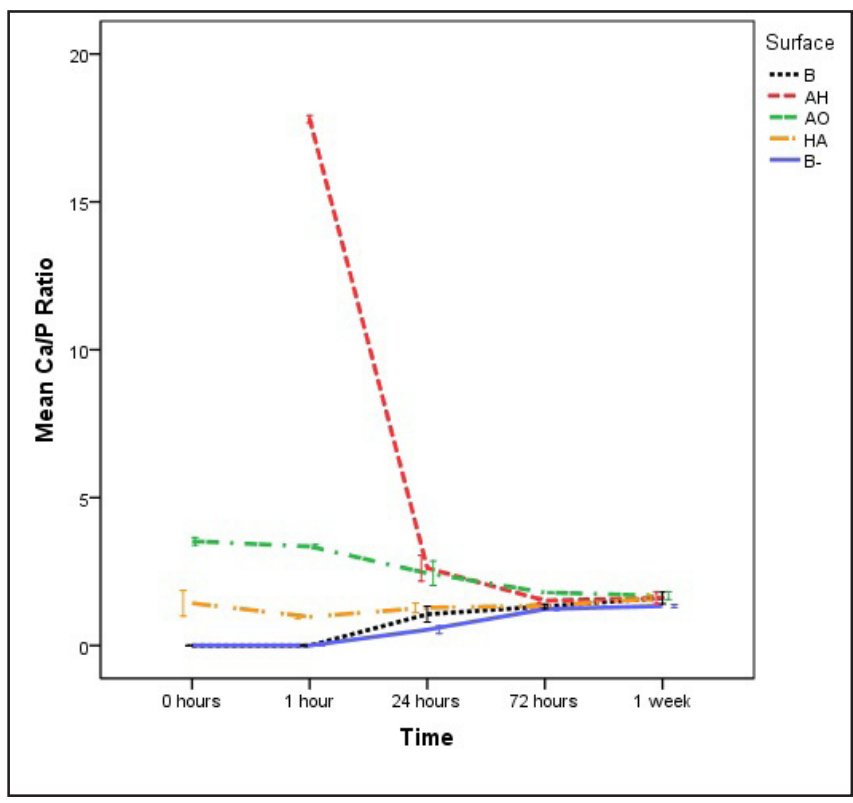

Figure 7. Calcium/phosphate ratio calculated from EDX measurements. $\mathrm{B}=$ blasted titanium; $\mathrm{AH}=$ alkali and heat treated; $\mathrm{AO}=$ anodically oxidized; $\mathrm{HA}=$ hydroxyapatite coated; $\mathrm{B}-=$ blasted titanium incubated in non laminin containing SBF. Mean values and standard errors are presented.

Table 1. Adsorbed laminin on the four different surface groups. The table presents mean values. Standard deviations are presented within parenthesis

\begin{tabular}{ccr}
\hline $\begin{array}{c}\text { SBF immersion } \\
\text { time }\end{array}$ & Surface type & Laminin (ng) (SD) \\
\hline \multirow{3}{*}{ 0 hours } & B & $94.00(1.16)$ \\
& AH & $94.33(1.86)$ \\
& AO & $100.00(1.16)$ \\
& HA & $95.33(2.40)$ \\
\hline \multirow{3}{*}{ 1 hour } & B & $767.33(107.16)$ \\
& AH & $805.67(129.97)$ \\
& AO & $828.67(176.62)$ \\
24 hours & HA & $953.67(24.10)$ \\
\hline \multirow{3}{*}{ 3 days } & B & $619.33(95.59)$ \\
& AH & $769.33(120.76)$ \\
& AO & $859.33(246.07)$ \\
& HA & $1111.33(415.43)$ \\
\hline \multirow{1}{*}{ week } & B & $501.67(69.96)$ \\
& AH & $785.67(182.50)$ \\
& AO & $445.33(102.00)$ \\
& HA & $556.67(50.35)$ \\
\hline & B & $601.00(18.50)$ \\
& AH & $817.67(133.30)$ \\
& AO & $1147.33(470.82)$ \\
& HA & $999.33(86.11)$ \\
\hline
\end{tabular}

$\mathrm{B}=$ blasted titanium;

$\mathrm{AH}=$ alkali and heat treated;

$\mathrm{AO}=$ anodic oxidized;

$\mathrm{HA}=$ hydroxyapatite coated 
$24 \mathrm{~h}$ of incubation. However, no significant differences of laminin levels could be detected among the different surface groups after equally long incubation time.

\section{DISCUSSION}

Laminin has been identified as one of the proteins being attached on biomaterial surfaces after the implantation process, and has been proposed to participate in osteoblast adhesion on biomaterials [22]. However, its biological role has not been studied compared to other important bone related proteins [39]. Previous in vitro studies have identified the integrin subunit $\beta 1$ as a mechanism involved in human osteoblast adhesion [27], and have suggested that laminin-1 recruits osteoprogenitor cells through an attachment effect $[\underline{25}, 26]$. Nevertheless, none of those studies has investigated the ability of laminin to precipitate on different titanium surfaces or its potential to precipitate $\mathrm{CaP}$.

The results from this study showed that the $\mathrm{Ca} / \mathrm{P}$ ratio was higher for the possibly bioactive surfaces after 1 and $24 \mathrm{~h}$ as compared to blasted titanium surfaces. The ability of the possibly bioactive surfaces to induce a higher calcium phosphate level at the initial incubation phase declined by time and no difference in the ratio was observed after one week of incubation. These findings are in agreement with the results presented by Stenport et al. [40]. However, it is important to keep in mind that the control blasted group had not been subjected to any surface modification leading to possibly bioactive properties which may explain why neither calcium nor phosphate were detectable prior to incubation or after one hour of incubation. Thus, the more rapid response of the possibly bioactive surfaces could be explained by the ability of initial crystals of calcium and phosphorous to promote further calcium phosphate precipitation, a process known as crystal growth [19]. Hence, the $\mathrm{Ca} / \mathrm{P}$ ratios illustrated in Figuure 6 include the sum of the calcium and phosphate originating in the surface treatment, and the crystals having precipitated during the SBF incubation. Interestingly, at $72 \mathrm{~h}$ and 1 week the $\mathrm{Ca} / \mathrm{P}$ ratio was approximately 1.67 , which corresponds to hydroxyapatite formation, and indicates that the formed $\mathrm{CaP}$ can be identified as hydroxyapatite. Previously performed studies examining the nucleation rate of calcium phosphate in SBF solution including BSA have not always examined the topography of the tested surfaces $[\underline{18}, \underline{20}, \underline{41}]$. In our study, we have examined three surface roughness parameters of the tested surfaces according to the norms for a complete topographic analysis [38]. All three tested parameters, $\mathrm{S}_{\mathrm{a}}, \mathrm{S}_{\mathrm{ds}}$ and $\mathrm{S}_{\mathrm{dr}}$, increased for all tested surfaces with incubation time, indicating a rougher surface created by the calcium phosphate precipitation. This finding is in agreement with the SEM observation.

In an earlier SBF study with four titanium surfaces claimed to be bioactive, i.e. fluoride etched, alkali and heat treated, anodically oxidated and hydroxyapatite coated, the evaluation of the BSA precipitation on surfaces was performed by counting the amount of nitrogen on the surfaces as an indirect way of protein detection. It was concluded that modified surfaces possessed a more rapid BSA precipitation compared to the blasted surfaces [40]. In the present study, we have labelled laminin with iodine-125, which detected the amount of protein more directly. Zeng et al. [21] compared BSA precipitation on hydroxyapatite, fluorapatite and pure titanium surfaces, and found that different surface composition and structure influenced the adsorption of BSA. The results of the present study demonstrated the ability of laminin to equally precipitate on various titanium surfaces within the first hour of incubation regardless of the underlying surface topography or chemistry. This finding suggests that laminin possesses the ability to precipitate easily on biomaterial surfaces.

All tested surfaces induced higher CaP precipitation when incubated in SBF containing laminin with a concentration equivalent to the human blood plasma as compared to blasted surfaces solely incubated in SBF [36]. A possible mechanism for laminin promoting $\mathrm{CaP}$ precipitation may be its function as a nucleation center. According to a morphological study examining the same laminin molecule that we utilized in the present study, laminin tends to assume a globular form when used for surface coating [42]. Some of the domains exposed from this protein conformation may act as nucleation centers for calcium ions thereby increasing the local calcium phosphate concentration, leading to enhanced nucleation ratio. In a recent study on osteoblasts, the effect of elevated extracellular calcium concentration was proposed to stimulate osteoblasts through the receptor activator of NF- $\mathrm{BB}$ ligand [43]. Hence, it is possible that the enhanced calcium phosphate formation observed in this study triggers osteoblast differentiation around laminin coated implants also when applied in vivo, acting as a complementary mechanism to the osteoblast activation by the integrin $\beta 1$ subunit. An additional advantage of the possible function of laminin as nucleation center is its possible incorporation within the calcium phosphates. Hence, the proposed model would provide beneficial sustaining of laminin by leading to lower clearance, and higher local concentration for a longer period of time, thereby leading to prolonged stimulation of the surrounding osteoblasts.

Nevertheless, despite the interesting findings from this study one has to keep in mind that in vivo protein 
interactions are more complex. Therefore more in vitro and in vivo studies are required in order to clarify the role of laminin in the interaction of biomaterials with the host bone tissue.

\section{CONCLUSIONS}

The results of the present study demonstrate the potential of laminin to equally precipitate on titanium surfaces subjected to various surface modifications, and to enhance apatite formation on blasted titanium surfaces when compared to blasted surfaces incubated in simulated body fluid in the absence of laminin. Among the tested surface modifications, alkali and heat treatment seemed to induce more rapid $\mathrm{CaP}$ precipitation. The findings of this study are intriguing since laminin may function as a nucleation center, thus locally elevating the calcium concentration, thereby having a positive effect on osteoblast differentiation. Nevertheless, since the in vivo protein interactions are more complex, further studies are required in order to clarify the role of laminin in the interaction of biomaterials with the host bone tissue.

\section{ACKNOWLEDGMENTS AND DISCLOSURE STATEMENTS}

The authors thank Agneta Askendal from the department of Applied Physics in Linköping University, Sweden for her help with protein labeling. This study was supported by the Swedish National Graduate School in Odontological Science. The authors also acknowledge the Swedish Research Council (K200952X-06533-27-3), Hjalmar Svenson Research Foundation, Sylvan Foundation, Wilhelm and Martina Lundgren Science Foundation, the Royal Society of Arts and Sciences in Göteborg and the Council for Research and Development in Södra Älvsborg, Sweden for funding the project.

\section{REFERENCES}

1. Hench L, Yamamuro T, Wilson J. Bioactive glasses and glass-ceramics. Handbook of Bioactive CeramicsBoca Raton: CRC Press, 1990. p. 7-23.

2. Williams DF, editor. The williams dictionary of biomaterials. 1st ed. Liverpool: Liverpool University Press, 1999.

3. Ellingsen JE. Pre-treatment of titanium implants with fluoride improves their retention in bone J Mater Sci Mater Med 1995;6(12). p. 749-753. [doi: 10.1007/BF00134312]

4. Kim HM, Miyaji F, Kokubo T, Nakamura T. Preparation of bioactive Ti and its alloys via simple chemical surface treatment J Biomed Mater Res 1996;32:409-417. [doi: 10.1002/(SICI)1097-4636(199611)32:3<409::AID-JBM14>3.0.CO;2-B]

5. Ishizawa H, Fujino M, Ogino M. Mechanical and histological investigation of hydrothermally treated and untreated anodic titanium oxide films containing Ca and P. J Biomed Mater Res. 1995 Nov;29(11):1459-68. [Medline: 8582915] [doi: 10.1002/jbm.820291118]

6. Blackwood DJ, Seah KH. Influence of anodization on the adhesion of calcium phosphate coatings on titanium substrates. J Biomed Mater Res A. 2010 Jun 15;93(4):1551-6. [Medline: 20014290]

7. Ramires PA, Romito A, Cosentino F, Milella E. The influence of titania/hydroxyapatite composite coatings on in vitro osteoblasts behaviour. Biomaterials. 2001 Jun;22(12):1467-74. [Medline: 11374445] [doi: 10.1016/S0142-9612(00)00269-6]

8. Xiao SJ, Textor M, Spencer ND, Wieland M, Keller B, Sigrist H. Immobilization of the cell-adhesive peptide Arg-GlyAsp-Cys (RGDC) on titanium surfaces by covalent chemical attachment. J Mater Sci Mater Med. 1997 Dec;8(12):867-72. [Medline: 15348806] [doi: 10.1023/A:1018501804943]

9. Tsiourvas D, Tsetsekou A, Arkas M, Diplas S, Mastrogianni E. Covalent attachment of a bioactive hyperbranched polymeric layer to titanium surface for the biomimetic growth of calcium phosphates. J Mater Sci Mater Med. 2011 Jan;22(1):85-96. Epub 2010 Nov 11. [Medline: 21069559] [FREE Full Text] [doi: 10.1007/s10856-010-4181-7]

10. Bhakta S, Pattanayak DK, Takadama H, Kokubo T, Miller CA, Mirsaneh M, Reaney IM, Brook I, van Noort R, Hatton PV. Prediction of osteoconductive activity of modified potassium fluorrichterite glass-ceramics by immersion in simulated body fluid. J Mater Sci Mater Med. 2010 Nov;21(11):2979-88. Epub 2010 Aug 20. [Medline: 20725768] [doi: 10.1007/s10856-010-4145-y]

11. Will J, Hoppe A, Müller FA, Raya CT, Fernández JM, Greil P. Bioactivation of biomorphous silicon carbide bone implants. Acta Biomater. 2010 Dec;6(12):4488-94. Epub 2010 Jul 6. [Medline: 20615484] [doi: 10.1016/j.actbio.2010.06.036]

12. Yada M, Inoue Y, Akihito G, Noda I, Torikai T, Watari T, Hotokebuchi T. Apatite-forming ability of titanium compound nanotube thin films formed on a titanium metal plate in a simulated body fluid. Colloids Surf B Biointerfaces. 2010 Oct 15;80(2):116-24. Epub 2010 May 31. [Medline: 20580538] [doi: 10.1016/j.colsurfb.2010.05.032] 
13. Kokubo T, Kushitani H, Sakka S, Kitsugi T, Yamamuro T. Solutions able to reproduce in vivo surface-structure changes in bioactive glass-ceramic A-W. J Biomed Mater Res. 1990 Jun;24(6):721-34. [Medline: 2361964] [doi: $10.1002 / \mathrm{jbm} .820240607]$

14. Peltola T, Pätsi M, Rahiala H, Kangasniemi I, Yli-Urpo A. Calcium phosphate induction by sol-gel-derived titania coatings on titanium substrates in vitro. J Biomed Mater Res. 1998 Sep 5;41(3):504-10. [Medline: 9659622] [doi: 10.1002/(SICI)1097-4636(19980905)41:3<504::AID-JBM22>3.0.CO;2-G]

15. Takadama H, Kim HM, Kokubo T, Nakamura T. TEM-EDX study of mechanism of bonelike apatite formation on bioactive titanium metal in simulated body fluid. J Biomed Mater Res. 2001 Dec 5;57(3):441-8. [Medline: 11523039] [doi: 10.1002/1097-4636(20011205)57:3<441::AID-JBM1187>3.0.CO;2-B]

16. Barrere F, Snel MM, van Blitterswijk CA, de Groot K, Layrolle P. Nano-scale study of the nucleation and growth of calcium phosphate coating on titanium implants. Biomaterials. 2004 Jun;25(14):2901-10. [Medline: 14962569] [doi: 10.1016/j.biomaterials.2003.09.063]

17. Kokubo T, Takadama H. How useful is SBF in predicting in vivo bone bioactivity? Biomaterials. 2006 May;27(15):290715. Epub 2006 Jan 31. Review. [Medline: 16448693] [doi: 10.1016/j.biomaterials.2006.01.017]

18. Liu Y, Layrolle P, de Bruijn J, van Blitterswijk C, de Groot K. Biomimetic coprecipitation of calcium phosphate and bovine serum albumin on titanium alloy. J Biomed Mater Res. 2001 Dec 5;57(3):327-35. [Medline: 11523027] [doi: 10.1002/1097-4636(20011205)57:3<327::AID-JBM1175>3.0.CO;2-J]

19. Combes C, Rey C.Adsorption of proteins and calcium phosphate materials bioactivity. Biomaterials. 2002 Jul;23(13):281723. Review. [Medline: 12059033] [doi: 10.1016/S0142-9612(02)00073-X]

20. Wen HB, de Wijn JR, van Blitterswijk CA, de Groot K. Incorporation of bovine serum albumin in calcium phosphate coating on titanium. J Biomed Mater Res. 1999 Aug;46(2):245-52. [Medline: 10380003] [doi: 10.1002/(SICI)1097-4636(199908)46:2<245::AID-JBM14>3.0.CO;2-A]

21. Zeng H, Chittur KK, Lacefield WR. Analysis of bovine serum albumin adsorption on calcium phosphate and titanium surfaces. Biomaterials. 1999 Feb;20(4):377-84. [Medline: 10048411] [doi: 10.1016/S0142-9612(98)00184-7]

22. Anselme K. Osteoblast adhesion on biomaterials. Biomaterials. 2000 Apr;21(7):667-81. Review. [Medline: 10711964] [doi: 10.1016/S0142-9612(99)00242-2]

23. Colognato H, Yurchenco PD. Form and function: the laminin family of heterotrimers. Dev Dyn. 2000 Jun;218(2):213-34. Review. [Medline: 10842354] [doi: 10.1002/(SICI)1097-0177(200006)218:2<213::AID-DVDY1>3.0.CO;2-R]

24. Hynes RO. Cell adhesion: old and new questions. Trends Cell Biol. 1999 Dec;9(12):M33-7. Review. [Medline: 10611678] [doi: 10.1016/S0962-8924(99)01667-0]

25. Roche P, Goldberg HA, Delmas PD, Malaval L. Selective attachment of osteoprogenitors to laminin. Bone. 1999 Apr;24(4):329-36. [Medline: 10221545] [doi: 10.1016/S8756-3282(98)00194-X]

26. Roche P, Rousselle P, Lissitzky JC, Delmas PD, Malaval L. Isoform-specific attachment of osteoprogenitors to laminins: mapping to the short arms of laminin-1. Exp Cell Res. 1999 Aug 1;250(2):465-74. [Medline: 10413600] [doi: $10.1006 /$ excr.1999.4518]

27. Gronthos S, Stewart K, Graves SE, Hay S, Simmons PJ. Integrin expression and function on human osteoblast-like cells. J Bone Miner Res. 1997 Aug;12(8):1189-97. [Medline: 9258748] [doi: 10.1359/jbmr.1997.12.8.1189]

28. Kim HM, Miyaji F, Kokubo T, Nakamura T. Effect of heat treatment on apatite-forming ability of Ti metal induced by alkali treatment. J Mater Sci Mater Med. 1997 Jun;8(6):341-7. [Medline: 15348733] [doi: 10.1023/A:1018524731409]

29. Kim HM, Miyaji F, Kokubo T, Nishiguchi S, Nakamura T. Graded surface structure of bioactive titanium prepared by chemical treatment. J Biomed Mater Res. 1999 May;45(2):100-7. [Medline: 10397963] [doi: 10.1002/(SICI)1097-4636(199905)45:2<100::AID-JBM4>3.0.CO;2-0]

30. Sul YT, Johansson C, Byon E, Albrektsson T. The bone response of oxidized bioactive and non-bioactive titanium implants. Biomaterials. 2005 Nov;26(33):6720-30. [Medline: 15975649] [doi: 10.1016/j.biomaterials.2005.04.058]

31. Sul YT, Johansson CB, Jeong Y, Albrektsson T. The electrochemical oxide growth behaviour on titanium in acid and alkaline electrolytes. Med Eng Phys. 2001 Jun;23(5):329-46. [Medline: 11435147] [doi: 10.1016/S1350-4533(01)00050-9]

32. Sul YT, Johansson CB, Albrektsson T. Oxidized titanium screws coated with calcium ions and their performance in rabbit bone. Int J Oral Maxillofac Implants. 2002 Sep-Oct;17(5):625-34. [Medline: 12381062]

33. Sul YT, Johansson CB, Petronis S, Krozer A, Jeong Y, Wennerberg A, Albrektsson T. Characteristics of the surface oxides on turned and electrochemically oxidized pure titanium implants up to dielectric breakdown: the oxide thickness, micropore configurations, surface roughness, crystal structure and chemical composition. Biomaterials. 2002 Jan;23(2):491-501. [Medline: 11761170] [doi: 10.1016/S0142-9612(01)00131-4]

34. Kjellin P, Andersson M. Synthetic nano-sized crystalline calcium phosphate and method of production patent. 2006 Aprl 25. [URL: http://www.freepatentsonline.com/EP1781568A1.html] [FREE Full Text]

35. Oyane A, Kim HM, Furuya T, Kokubo T, Miyazaki T, Nakamura T. Preparation and assessment of revised simulated body fluids. J Biomed Mater Res A. 2003 May 1;65(2):188-95. [Medline: 12734811] [doi: 10.1002/jbm.a.10482]

36. Werle E, Diehl E, Hasslacher C. Levels and molecular size distribution of serum laminin in adult type I diabetic patients with and without microangiopathy. Metabolism. 1998 Jan;47(1):63-9. [Medline: 9440479] [doi: 10.1016/S0026-0495(98)90194-9] 
37. Benesch J, Askendal A, Tengvall P. Quantification of adsorbed human serum albumin at solid interfaces: a comparison between radioimmunoassay (RIA) and simple null ellipsometry. Colloids Surf B Biointerfaces 2000;18:71-81. [doi: 10.1016/S0927-7765(99)00136-8]

38. Wennerberg A, Albrektsson T. Suggested guidelines for the topographic evaluation of implant surfaces. Int J Oral Maxillofac Implants. 2000 May-Jun;15(3):331-44. [Medline: 10874798]

39. Jimbo R, Mikaelsson I, Koskela A, Sul YT, Johansson CB. Protein adsorption to surface chemistry and chrystal structure modification of titanium surfaces. J Oral Maxillofac Res 2010 (Jul-Sep);1(3):e3. [URL: http://www.ejomr.org/JOMR/archives/2010/3/e3/e3ht.htm] [doi: 10.5037/jomr.2010.1303]

40. Stenport V, Kjellin P, Andersson M, Currie F, Sul YT, Wennerberg A, Arvidsson A. Precipitation of calcium phosphate in the presence of albumin on titanium implants with four different possibly bioactive surface preparations. An in vitro study. J Mater Sci Mater Med. 2008 Dec;19(12):3497-505. Epub 2008 Jul 15. [Medline: 18622767] [doi: $10.1007 / \mathrm{s} 10856-008-3517-\mathrm{z}$ ]

41. Combes C, Rey C. Adsorption of proteins and calcium phosphate materials bioactivity. Biomaterials. 2002 Jul;23(13):281723. Review. [Medline: 12059033] [doi: 10.1016/S0142-9612(02)00073-X]

42. Rodríguez Hernández JC, Salmerón Sánchez M, Soria JM, Gómez Ribelles JL, Monleón Pradas M. Substrate chemistry-dependent conformations of single laminin molecules on polymer surfaces are revealed by the phase signal of atomic force microscopy. Biophys J. 2007 Jul 1;93(1):202-7. Epub 2007 Apr 6. [Medline: 17416620] [doi: 10.1529/biophysj.106.102491] [FREE Full Text]

43. Lee HL, Bae OY, Baek KH, Kwon A, Hwang HR, Qadir AS, Park HJ, Woo KM, Ryoo HM, Baek JH. High extracellular calcium-induced NFATc3 regulates the expression of receptor activator of NF- $\kappa$ B ligand in osteoblasts. Bone. 2011 Aug;49(2):242-9. Epub 2011 Apr 14. [Medline: 21514407] [doi: 10.1016/j.bone.2011.04.006]

\section{To cite this article:}

Bougas K, Stenport VF, Currie F, Wennerberg A. In vitro Evaluation of Calcium Phosphate Precipitation on Possibly Bioactive Titanium Surfaces in the Presence of Laminin.

J Oral Maxillofac Res 2011;2(3):e3

URL: http://www.ejomr.org/JOMR/archives/2011/3/e3/v2n3e3ht.pdf doi: $10.5037 /$ jomr.2011.2303

Copyright (C) Bougas K, Stenport VF, Currie F, Wennerberg A. Accepted for publication in the JOURNAL OF ORAL \& MAXILLOFACIAL RESEARCH (http://www.ejomr.org), 19 July 2011.

This is an open-access article, first published in the JOURNAL OF ORAL \& MAXILLOFACIAL RESEARCH, distributed under the terms of the Creative Commons Attribution-Noncommercial-No Derivative Works 3.0 Unported License, which permits unrestricted non-commercial use, distribution, and reproduction in any medium, provided the original work and is properly cited. The copyright, license information and link to the original publication on (http://www.ejomr.org) must be included. 